\title{
LO PITAGÓRICO EN LA FILOSOFÍA DE SUHRAWARDÎ Y LA ESCUELA ISHRAQÎ
}

\section{THE PYTHAGOREAN IN THE PHILOSOPHY OF SUHRAWARDÎ AND THE ISHRAQÎ SCHOOL}

\author{
Amílcar Aldama Cruz ${ }^{1^{*}}$ \\ $1^{\star}$ Universidad Internacional Al-Mustafá (Irán) \\ Email: amilcaraldama@gmail.com ORCID: https://orcid.org/0000-0002-2401-7283
}

Recibido: 17/10/2021 Aceptado: 12/01/2022

Cómo Citar: Aldama Cruz, A. (2022). Lo pitagórico en la filosofía de Suhrawardî y la escuela ishraqî. Dialektika: Revista De Investigación Filosófica y Teoría Social, 4(9), 28-46. https://doi.org/10.51528/dk.vol4.id69

\begin{abstract}
Resumen: El objetivo de este artículo es describir la influencia y relectura del pensamiento pitagórico en los filósofos islámicos persas de la escuela ishraqî o iluminativa, centrada en su fundador Shihâd al-Dîn Yahyâ Suhrawardî (1154-1198), y como estas relecturas fueron sistematizadas posteriormente por el filósofo persa Mullâ Ṣadrâ (1571-1635). Esta relectura de la filosofía islámica del pitagorismo se dio gracias al proceso de traducción al árabe de las obras de Platón y los filósofos neoplatónicos en el contexto árabe-islámico, logrando así que se articularan los temas epistemo-ontológicos referentes al alma, la metempsicosis, la percepción, el conocimiento por presencia, la autoconciencia, la ipseidad y la realidad. En dichos temas filosóficos late la impronta órfico-pitagórica de pensadores antiguos como Heráclito, Parménides, Empédocles, Sócrates y Platón, que fueron asumidos e integrados en el contexto monoteísta del islam.
\end{abstract}

Palabras clave: pitagorismo, ishraqî, autoconciencia, alma, realidad.

\begin{abstract}
The objective of this article is to describe the influence and reinterpretation of Pythagorean thought on the Persian philosophers of the ishraqî or Illuminative school, centered on its founder Shihâd al-Dîn Yahyâ Suhrawardî (1154-1198), and how these reinterpretations were later systematized by the Persian philosopher Mullâ Sadrâ (1571-1635). This reinterpretation of the Islamic philosophy of Pythagoreanism was made by the process of translating into Arabic the works of Plato and the Neoplatonic philosophers in the Islamic context. In this way, epistemological and ontological themes related to the soul, metempsychosis, perception, knowledge by presence, self-consciousness, selfhood and reality were articulated in this context. In these philosophical themes is the OrphicPythagorean influence of ancient thinkers such as Heraclitus, Parmenides, Empedocles, Socrates, and Plato, who were integrated into the monotheistic context of Islam.
\end{abstract}

Keywords: pythagoreanism, ishraqî, self-consciousness, soul, reality. 


\section{INTRODUCCIÓN}

$\mathrm{M}$ aría Zambrano en su ensayo "La condenación de los pitagóricos" realiza una valoración de cómo Aristóteles asumió el "descubrimiento" del alma, por parte de los órficos y desarrollada por los pitagóricos, sin darle el mérito a la escuela de Crotona, una postura que podría estar dirigida contra el criptopitagorismo de su maestro Platón. Zambrano expone esta idea de la siguiente manera:

"Uno de los asuntos de la historia de la filosofía que mayor asombro producen es que el alma haya sido descubrimiento de los filósofos del número, antes que de los de la palabra; hasta el punto de que no podemos saber si los de la palabra - sustancialitas al fin, salvados en el sustancialismo aristotélico - la hubieran descubierto. Que Aristóteles la descubra, y aun la sistematice, nada quiere decir; estaba ya ahí y no era eludible. Al contrario, era lo que había que conceder al pitagorismo, sin decirlo. Pues a partir de Aristóteles sucederá algo normal con el pitagorismo. Lo que normalmente sucede con los vencidos, en cualquier historia de que se trate: se toma de los vencidos lo que hace falta sin nombrarlos; se les concede la razón ineludible, mas apoderándose de ella, y trasladándola al campo del vencedor (...). La suerte de la razón del vencido es convertirse en semilla que germina en la tierra del vencedor" $(2012,90)$.

Es bajo esta dinámica, que a decir de Zambrano "cualquier semilla pitagórica nacerá en otro suelo, bajo otro nombre y mezclada a otra sustancia", se dio la germinación del pitagorismo o neopitagorismo en la filosofía islámica. Justamente unas de las primeras traducciones del griego al árabe del sustantivo pitagórico (ó ПuӨ $\theta \gamma o ́ \rho \varepsilon o t)$, en la Bagdad del siglo X, fue traída de la "Metafísica" aristotélica. El traductor Abû Ali Naẓhîf tomó este sustantivo como alfizâgûrîwan (الفيثاغوريون) de la "Metafísica” (987ª 13), y ya en obras filosóficas peripatéticas del contexto islámico lo encontramos en varias aserciones, como en el texto "Risâl"

1 “Shihâb al-Dîn Yahyâ ibn Habash ibn Amîrak Abu'l-Futûh Suhrawardî, es bien conocido en la historia de la filosofía islámica como el maestro de la teosofía oriental (Shaykh al-Ishrâq), una referencia a su posición aceptada como el fundador de una nueva escuela de filosofía distinta a la escuela peripatética (madhhab, o maktab al-mashshâ' ûn). Suhrawardî nació en la pequeña ciudad de Suhraward en el noreste de Persia en el año 549/1154. Se enfrentó a una violenta muerte por ejecución en Alepo en el año 587/1191 y, por esto a veces se le llama el Maestro Martirizado (al-Shaykh al-

D I A LEKTIKA • 2022,4 ( 9): 28 - 46.

ISSN 2707-3386 de al-Fârâbî donde se emplea como âșhâb-u fûzâgûris y en las obras de Averroes se utiliza como fizâgûris (فيثاغنوس).

La doxografía de Pitágoras de Samos en el contexto islámico se hace manifiesta de forma particular en el egipcio Ibn alQifțî (1172-1248) autor de la obra "Ta'rîh al-hukamâ" o "Historia de los filósofos", donde el filósofo presocrático es mencionado diecisiete veces como uno de los más antiguos sabios, junto a una curiosa lista integrada por Hermes Trimegistro, Esculapio, Empédocles de Agrigento y Anaxágoras, aunque la mención de Heráclito y Parménides no es visible. Ibn al-Qifțî, quien fungió como secretario de corte del sultán Saladino en Jerusalén, fue contemporáneo del filósofo persa del cual germinó con mayor fuerza el pitagorismo en el contexto filosófico islámico, Shihâd al-Dîn Yahyâ Suhrawardî (1154-1198) ${ }^{1}$, quien fuera ejecutado en Alepo por orden del mismo sultán Saladino.

La influencia de un pitagorismo subterráneo, manifiesto bajo un neoplatonismo oriental, es numerosa en la obra de Suhrawardî y de los seguidores de su escuela llamada ishraqî o iluminativa. Ello es constatable en el abordaje y desarrollo de conceptos pitagóricos a partir del manejo de las traducciones de Platón, pero sobre todo de los textos y comentarios neoplatónicos al árabe. Algunos de estos conceptos órfico-pitagóricos serán los de alma $(\psi v \chi \chi)$ y

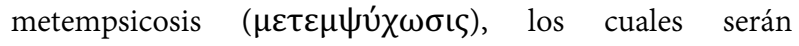
sistematizados en la ontología y epistemología ishraqî, conduciéndolos al tratamiento de conceptos como los de transmigración o tanâsukh, autoconciencia o shu'ur, y conocimiento por presencia o 'ilm hudûurî. Es de igual manera atrayente para el investigador hallar en la filosofía ishraq $\hat{\imath}$ lazos invisibles con lo apolíneo, eje conductor tanto de Pitágoras como de Heráclito, Parménides y Empédocles, pero no en la simple analogía de lo solar y la luz que rigen tanto lo apolíneo ( $\alpha u ́ \gamma \hat{\varepsilon}$ ) como lo ishraqî (نور), sino en el mismo concepto de manifestación mediante el rapto

Maqtîl). Su gran obra " escrita en 582/1186. Su principal biógrafo, Shams al-Dîn Muhammad Shahrazûrî, afirma en su "Nuzhat al-arwâh" (Placeres espirituales) que Suhrawardî tenía treinta años cuando completó otra de sus principales obras filosóficas, "al-Mashâri'wa'lmutârahât" o "Las Encrucijadas y las Conversaciones" (concluido en c. 579/1183). Su filosofía es una gran síntesis del pensamiento griego neoplatónico y mazdeísta con la filosofía y mística islámica. 


\section{(iil) DiALETTIKA A}

epifánico, la manía y el shuhûd como principio intensivo de un verdadero saber. Además, Suhrawardî realiza una síntesis de un pitagorismo-platónico con la tradición mazdea de Persia, lo cual podría ser una relectura de la cosmovisión mazdeista que, según los doxógrafos, aprendió Pitágoras en el Oriente. ${ }^{2}$

El traer a consideración los conceptos ontológicos y epistemológicos de un filósofo persa del siglo XII y su escuela, de alguna forma, deja de ser un mero ejercicio enmarcado en la historia de la filosofía medieval, para convertirse en una útil herramienta de análisis en el contexto actual del pensamiento filosófico. Prueba de ello son los estudios recientes sobre la ontología y la epistemología de Suhrawardî, realizados tanto en el contexto académico occidental, donde destacan investigadores como el finlandés Jari Kaukua, el norteamericano Muhammad Faruque, la canadiense Roxanne D. Marcotte y el brasileño Mateus Domingues Da Silva, como en el contexto académico iraní con los investigadores Seyyed Yazdânpanâh y Mahdî 'Abbâs-zâdeh. Suhrawardî ha sido un filósofo en parte desdeñado por los partidarios de la muerte de la filosofía islámica con Averroes, o realzado únicamente como un místico platónico oriental (Henry Corbin), pero a pesar dichos análisis en la actualidad Suhrawardî aporta interesantes ideas a los campos del subjetivismo, intencionalidad, la analítica de identidad e individuación, las actitudes proposicionales y modalidades.

\footnotetext{
2 Según la doxografía sobre Pitágoras, éste tuvo contacto con Zoroastro. Existen testimonios escritos de esa relación con el mazdeísmo por parte de Pitágoras. Apuleyo comenta: "Algunos dicen que cuando Pitágoras fue enviado a Egipto entre los prisioneros de Cambises, tuvo como maestros suyos a los Magos persas y, en particular, a Zoroastro, el maestro de todos los conocimientos secretos." Por otro lado, dice Porfirio: "Pitágoras enseñó, sobre todo, a decir la verdad, porque éste era el único modo de asemejarse a Dios. Porque, como aprendió de los Magos, el cuerpo de dios, a quien ellos llaman Ahura Mazda, se asemeja a la luz, y su alma a la verdad."

${ }^{3}$ Desde el mismo mito que da explicación a la transmigración o metempsicosis hay una ruptura con las teogonías oficiales como la de Hesíodo. En el mito órfico Zeus educaba a su pequeño hijo Dioniso para dejarlo como regente del cosmos. Los titanes celosos de esto atraen a Dioniso con juguetes y espejos, luego lo desmiembran, lo asan y lo devoran. Zeus al constatar el crimen fulmina a los titanes con un rayo, y de los restos de los titanes y Dioniso nacen los hombres. Así en su conformación los hombres tienen una parte divina y otra parte material (la tierra). La parte divina, el alma, a su vez tiene una parte positiva, la de Dioniso, y otra parte negativa, la de los titanes. Existe un crimen inicial que debe ser
}

Por otro lado, realizar el estudio de los vasos comunicantes existentes entre las doctrinas órfico-pitagóricas y la filosofía islámica aporta una nueva perspectiva de la relectura realizada por los filósofos islámicos del saber griego, que no quedó como un mero comentario de las ideas, sino que tributó a un nuevo desarrollo del pensamiento filosófico.

\section{EL CONCEPTO DEL ALMA Y DE METEMPSICOSIS EN EL PITAGORISMO}

La doctrina del alma y la metempsicosis como corolario de la inmortalidad forma parte de las enseñanzas más antiguas del pitagorismo; Werner Jaeger menciona que Heródoto consideraba la doctrina del metempsicosis o transmigración de las almas como típica de los más antiguos pitagóricos. Dicha doctrina es tomada por los pitagóricos de los ritos órficos (o las llamadas "cosas órficas"), una doctrina con una carga soteriológica que rompía con la mirada escatológica de la religión olímpica y de los mitólogos de Zeus ${ }^{3}$, ya que aportaba una teología de salvación por medio de una dualidad moral que fundamentaba la justicia y la retribución en el más allá, luego de un ciclo de purificación y un recto modelo de vida en las diversas transmigraciones. Existe testimonio de esa visión órfica en los papiros de Derveni, en las láminas de Olbia (siglo V a. C) y otros textos antiguos ${ }^{4}$.

expiado, por lo que el alma debe purificar todo lo que de negativa tenga, de aquí que exista los ciclos de transmigración que exigen un modelo de vida. Esto lo expuso Dion Crisóstomo (30.10): “Todos los hombres somos de la sangre de los Titanes, así como aquéllos son enemigos de los dioses y lucharon contra ellos, tampoco nosotros somos amigos suyos, sino que somos mortificadores por ellos $y$ nacemos para ser castigados (...) Los que morimos tras haber sido ya suficientemente castigados nos vemos liberados y escapamos. El lugar que llamamos mundo es una cárcel penosa y sofocante preparada por los dioses." (Dion de Prusa. Discursos. Obra completa. Madrid: Editorial Gredos). Por otro lado, era creencia común del griego que el mal que realizaba una persona sería castigado por la generación que le precedía, los órficos crearon la teoría que el pago lo haría la misma individualidad en otras transmigraciones.

4 "Pues el alma, mudada según los ciclos del tiempo

transmigra de hombre a unos y otros animales

unas veces viene a ser caballo, otras...

otras veces oveja, otras, ave de pavoroso aspecto,

otras en cambio cuerpo canino y voz profunda,

y estirpe de gélidas sierpes que se arrastra en la divina tierra"

(Orphicorum fragmenta 338, de las Rapsodias). 
Autores posteriores, como Eurípides y Platón, dejan constancia de las ideas órficas en sus obras. Platón en el "Menón" $81^{\text {a }}$ describe de esta manera la creencia órfica:

"...afirman, en efecto, que el alma del hombre es inmortal y que unas veces llega a un término - al que llaman morir - y otras de nuevo llega a ser, pero que no perece nunca; $y$ que por eso es necesario pasar la vida con mayor santidad posible".

Para los pitagóricos, como herederos de esta doctrina del ciclo del alma y su conformación, el alma humana es una emanación del alma universal, no es engendrada ni producida con el cuerpo, sino que procede de lo externo, puede vivificar sucesivamente diferentes cuerpos, y existir también en las regiones etéreas por algún tiempo sin estar unida a ningún cuerpo humano o animal. Esta teoría contiene dos ideas fundamentales que germinarán en otros contextos filosóficos: la idea de la inmortalidad del alma humana, y la idea de las penas y recompensas después de la muerte. De igual forma los pitagóricos distinguían en el alma humana dos partes: una superior, perteneciente al orden inteligible, origen y asiento de la inteligencia y de la voluntad; otra inferior, perteneciente al orden sensible, origen y razón de los sentidos y pasiones. La primera, o sea la parte racional del alma, tiene su regencia en la cabeza; la inferior reside en determinadas vísceras, pero principalmente en el corazón, al que atribuían las manifestaciones del apetito irascible, y en el hígado, en donde colocaban las pasiones de la parte concupiscible. Esta fisiología espiritual será asumida en algunas escuelas mística- filosóficas islámicas. Según el testimonio de Aristóteles, los pitagóricos definían el alma como: "un número que se mueve a sí mismo". Es probable que con esta definición querían significar que el alma humana es una esencia simple que tiene en sí misma el principio de sus actos, o sea una unidad dotada de actividad espontánea. Mucho se ha discutido sobre el carácter místico que posee la escuela itálica (se ha llegado a hablar de técnicas chamánicas del éxtasis practicadas tanto por los pitagóricos como por Parménides y Empédocles) en contraposición a la

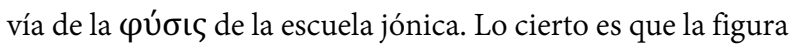
de Pitágoras ha estado siempre revestida de un aurea de teúrgo, en gran medida debido la doxografía posterior, en especial la neoplatónica de Jámblico y Porfirio. Mucho de ese imaginario neoplatónico es el que pasa al contexto islámico a través de las traducciones al árabe de los textos filosóficos griegos, y llega tanto a los doxógrafos como a los filósofos islámicos, en especial a la escuela ishraqî.

\section{PITÁGORAS EN LA FILOSOFÍA ISHRAQI}

La figura de Pitágoras (en árabe Fîzâgûris) es muy reverenciada en la escuela ishraqî, como uno de los iniciadores de la sabiduría que versa sobre los secretos y vías del alma. Debido a que la lectura que tuvo Suhrawardî de Pitágoras fue neoplatónica, éste se centrará en este neopitagorismo que aborda el tema del alma, y no tocará el tema del arché ( $\alpha \rho \chi \eta ́)$ como número ( $\alpha \rho \imath \theta \mu o ́ \varsigma)$, o sea, la doctrina de que los números establecen los principios o los elementos constitutivos de las cosas.

Suhrawardî ve en Pitágoras el soporte de una colosal estructura que se concreta en Platón, esta es la ciencia de la intuición o el conocimiento presencial -'ilm hudûrî- علم) حضورى), también denominado por Suhrawardî como $d z \hat{u} q$ (ذوق), que significa comúnmente sabor, pero que en terminología mística refiere a la intuición. Dice Suhrawardî sobre lo anterior en su obra "Hikmat al-ishrâq" (La sabiduría oriental):

"Esta ciencia es la intuición (dzûq) misma del inspirado e iluminado Platón, guía y maestro de la filosofía (hikmat) y de los que vinieron antes de él desde la época de Hermes "el padre de los filósofos" hasta la época de Platón, incluyendo tan poderosos pilares de la filosofía como Empédocles, Pitágoras y otros" (Traducción del autor) $(2014,277)$.

Sobre este mismo fragmento de Hikmat al-ishrâq comenta el filósofo ishrâqî Quṭb al- Dîn Shîrâzî (1237-1311), en su "Sharh Hikmat al-ishrâq" (Comentario a la Sabiduría oriental):

"Y así ha sido la intuición [ o cualidad directa de la experiencia directa o mística] de todos los sabios antecesores de Platón, desde el tiempo de Hermes de Egipto, conocido como el profeta Idris (que la paz sea con él) hasta la época de Platón y los grandes pensadores como Empédocles y su discípulo Pitágoras, y su discípulo Sócrates y su discípulo Platón, siendo éste el sello de la Gente de la Intuición (hikmat zauqiyat). Ya luego de él se difundió la sabiduría discursiva (sofistica- dialéctica) y gradualmente se añadieron muchas ramas innecesarias 
hasta la época en que desaparecieron los principios necesarios." (Traducción de autor) $(2005,19)$.

Es común en estos autores el equívoco cronológico de tomar a Empédocles como maestro de Pitágoras. De igual modo es notable la no mención de Heráclito y de Parménides en dicho linaje, el primero crítico de la figura de Pitágoras a quien acusó de polimatía y el segundo un pitagórico heterodoxo, lo que hace tentadora la especulación a un cierto prejuicio ishrâqî hacia estas dos figuras, pero habría que valorar qué información llegó al contexto islámico, a partir de las traducciones al árabe, sobre estos dos presocráticos. Incluso se sabe que el rey persa Darío invitó a Heráclito a Persépolis

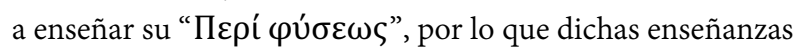
estarían en lengua pahleví o persa antiguo, y siendo Suhrawardî perpetuador de las enseñanzas pretéritas de Persia debería haber tenido noticias de ellas. Aun así, en un pensador ishrâqî como Mîr Damâd (m. 1631-32) es visible una articulación de conceptos heraclíteos sobre los diversos tipos de temporalidad. Desde el punto de vista del "tiempo"; Mîr Dâmâd distingue tres dimensiones diferentes en la composición ontológica del mundo del ser: sarmad (سرمد), "eterno" o la dimensión de la eternidad, dahr (دهر), "atemporal" o la dimensión de la atemporalidad del ser, y zamân (زمان), “tiempo" o la dimensión temporal de las cosas empíricas, que se corresponden con los modos de declinación del tiempo en Heráclito de Éfeso: Aidión (Aĩo เóv) temporalidad perpetua y sincrónica solo vista desde la vida precontinua, sin cambios ni movimientos, el tiempo de lo divino; Aión (Aĩóv), temporalidad vicaria e intensiva, una plenitud modal que en la perspectiva heraclítea enlaza a los antifáseos ( $\alpha \nu \tau \iota \varphi \alpha ́ \alpha \varepsilon 0 \varsigma)$ o contradictorios por su diferencia con la mediación del movimiento del Kairós o "lo

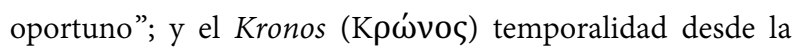
perspectiva de la muerte al ser devoradora de la vida, es extensa, diacrónica-cronológica por ocupar un locus y rige la plenitud de la unidad en lo cuantitativo.

Volviendo a Suhrawardî y sus comentaristas, en éstos prima el hecho de destacar el papel de estos filósofos antiguos como pilares de la sabiduría (âsâțîn al-hikmat) de la intuición y la utilización de lo mistérico o el secreto como vía pedagógica.

En referencia a la frase de Suhrawardî: "و كلمات الأوّلين مرموزة" (2014, 277) “y las palabras de los Primeros fueron mistéricas", Quṭb al- Dîn Shîrâzî realiza la siguiente glosa:

"Las palabras de los Primeros (los antiguos) fueron mistéricas, pues Hermes, Empédocles, Pitágoras, Sócrates y Platón utilizaban continuamente el secreto en sus palabras (enseñanzas), ya sea como un fortalecimiento para la mente por la inquietud del pensamiento." (traducción del autor) $(2005,20)$.

El filósofo persa ishraqî Shams al Din Muhammad alShahrazûrî (siglo XIII), gran comentador de Suhrawardî, en su libro "Rasâ'il al-shajarah al-ilâhiyyah" (Tratado del árbol divino y los secretos teosóficos) sistematiza el pensamiento ishraqî exponiendo un supuesto acúsmata de Pitágoras:

"Y dijo el sabio Pitágoras: Si aceptas lo que te dije sobre la obtención de las ciencias de la sabiduría y la inmaterialidad (del alma) en el mundo de la generación y la corrupción (sabrás entonces que) cuando dejes este cuerpo tu lugar estará en el cielo, entonces serás como un nadador celeste y no regresarás a tu estado humano ya que no serás receptor de la muerte." $(2005$, T.1, 9)

Se entiende en la frase anterior que no es pitagórica, ya que en ella se emplea los términos takawun (نَكَّون o generación y fasâd (فساد) o corrupción, términos aristotélicos por

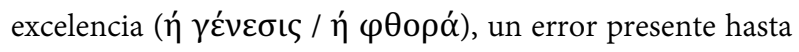
en el fragmento del poema de Anaximandro por una incorporación tardía: "De donde las entidades presentes tienen su origen ( $\gamma \varepsilon \dot{v} \varepsilon \sigma i ́$ ), hacia allí tiene lugar su corrupción

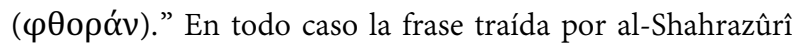
alude a la condición del alma en su estado de plenitud y emancipación, al comparar este estado al de un nadador en el cielo, dicho elemento refiere con mayor fuerza al argumento del "hombre volador" o del "hombre suspendido en el aire", experimento mental de Avicena (Ibn Sînâ) para defender la existencia del alma y el conocimiento por presencia, por lo cual sería una frase apócrifa de Pitágoras, o más bien una argumentación aviceniana en boca del sabio de Samos. Sobre este experimento mental aviceniano se hablará posteriormente.

Por su parte Manșûr Dashtakî Shîrâzî (m. 1542), filósofo persa que inaugura la escuela de Shiraz, en su libro "Îshrâq hayâkil al-nûr" (libro que comenta las doctrinas de Suhrawardî), expone la herencia de Pitágoras y los demás sabios antiguos desde una lectura neoplatónica:

"Puesto que Platón, Hipócrates, Pitágoras, Empédocles y otros sabios antiguos de las cuestiones divinas creían en las categorías de las ideas imaginales inmutables (arquetipos), no en un lugar iluminado u oscuro; ellos creían que estas ideas son sustancias inmateriales separadas de las materias fijas en el pensamiento, imagen y alma, y que estas materias son apariciones de las ideas suspendidas que existen en los objetos carentes de lugar. También creían en la existencia de dos mundos: 
el mundo intelectual ... y el mundo de las formas." (traducción del autor) (2003, 252).

En este fragmento aparece el nombre de Hipócrates (بقر اط), pero se trata de un error de trascripción en el texto de la letra inicial “ $b a ”(ب)$, pues el nombre Sócrates (سقر اط), más lógico en el contexto y mencionado dentro del linaje de sabios antiguos, se escribe con una letra "sin" (w) al comienzo. Se aprecia en este fragmento el hecho de que para los filósofos ishraqî Pitágoras era un defensor de la teoría de las ideas de Platón, dándose en ellos una difuminación de lo pitagórico y lo platónico desde la relectura neoplatónica.

Pero el punto de mayor complejidad es cómo logra conciliar la escuela ishraqî el concepto pitagórico de metempsicosis dentro de la tradición coránica que valida una única existencia terrena y la resurrección al fin de los días. Suhrawardî en su "Hikmat al-ishrâq" dedica la primera parte del capítulo dedicado al tema de la resurrección, la profecía y los sueños a la cuestión de la rencarnación o tanâsukh (تناسخ). Aquí Suhrawardî revisará los argumentos a favor y en contra de la idea de la transmigración de las almas o metempsicosis que no son concluyentes, de modo que no parece rechazar por completo la posibilidad de algún tipo de transmigración de las almas, especialmente para las almas imperfectas o miserables. Sin embargo, algunos de sus comentaristas como Shams al Din Muhammad al-Shahrazûrî y Quṭb al- Dîn Shîrâzî opinaron que él si defendía una especie de metempsicosis, siendo legitimada por ellos, acto que es un punto de quiebre con la doctrina tradicional islámica, si bien algunas sectas islámicas, como los alawitas, conservan la creencia en la transmigración de las almas. Es probable que a este elemento dentro de la filosofía ishraqî se le deba la aceptación que tuvo dentro de la India durante los siglos XVI y XVII, que se caracterizó en una literatura que unía la tradición shiita y sufí con el mazdeísmo, el maniqueísmo y el budismo Mahayana.

Sobre el tema del tanâsukh o metempsicosis escribió filósofo ishraqî 'Izza al -Dawla Ibn Kammûna (m. 1284) en su libro "Al-Kâshif, al-Jadîd fîl-hikma” expone lo siguiente:

"Metempsicosis: En los cuerpos de género como: humano, animal, vegetal, mineral. Y fueron creadas de las individualidades corpóreas que fueran convenientes

${ }^{5}$ Apolo como deidad de origen ajeno a Grecia, tiene su correlato con la deidad hitita Apaliuna "padre Luz" o con la deidad acadia Aplu Enlil con conexión con el dios babilonio del sol. Su rastreo dentro para la pertenencia del alma de manera pre-eterna. Al alma humana por su antigüedad le será necesaria la trasmigración, porque es imposible la existencia de lo que no tenga limitación para las almas, pues es obligatorio que las causas sean finitas" $(2003,350)$.

Estos argumentos sobre el tanâsukh serán trabajados y puesto en cuestión por el filósofo persa Mullâ Șadrâ (15711635), el cual realizó glosas al comentario del "Hikmat alishrâq" realizado por Quṭb al- Dîn Shîrâzî, evaluando la relación del alma con el cuerpo como la misma relación que posee la forma (صورت) y la materia (مادّه). Desde la perspectiva ontológica de Șadrâ si la forma o la materia es retirada, su complemento, sea la materia o la forma, también saldría de la existencia, por lo que a su juicio sería absurdo argumentar que la forma ha transmigrado dentro de otra materia o viceversa, ya que si el todo desapareciera en su lugar se formaría un nuevo e íntegro todo. Șadrâ utilizará su concepto de movimiento sustancial o harakat al- yaûharî para invalidar el argumento de la transmigración de las almas. Este argumento parte de que el alma y el cuerpo son un potencial inicial y cuando estas potencialidades son gradualmente realizadas el alma y el cuerpo, como un todo complejo, se mueven de manera ascendente en un proceso evolutivo; este no es el caso de cuando el alma se mueve sola mientras el cuerpo permanece extático, sino que el todo se mueve a través de un perfeccionamiento gradual hacia un nuevo estatus de existencia. Este análisis que desarrolla Mullâ Șadrâ en textos filosóficos como "Al-Shawâhid al-rubûbiyya fi l-manâhij alsulûkiyya”, tocará el tema de las almas sin desarrollar o almas imperfectas, tema abordado por Suhrawardî en "Hikmat alishrâq" en el apartado sobre el tanâsukh, y desarrollará a partir de este tema nociones como el de corporización activa o tayasum a'mâl (تجسم اعمال) y evolución o takâmul (تكامل).

\section{MANIA, AUTOCONCIENCIA Y CONOCIMIENTO POR PRESENCIA}

Retomando lo dicho por Suhrawardî sobre la visión de lo marmûzat (مرموزة) o lo mistérico en las palabras de los antiguos sabios, esta mención nos lleva a la referencia de los misterios de Apolo $^{5}$ que Pitágoras, como cuenta la doxografía, seguía, por lo que la escuela pitagórica estuvo

de la cosmovisión mazdeista está en la deidad persa al Mithras, correlato solar de Apolo, que será de influencia en la filosofía îshrâqî. 


\section{(iA) DiALEKTILA}

bajo la égida de esta deidad. El filósofo y filólogo italiano Giorgio Colli refiere como Pitágoras fue llamado en Crotona “Apolo Hiperbóreo", advocación apolínea concerniente a la región del norte donde marcha el dios cada invierno para la purificación ${ }^{6}$, dejando Delfos a Dionisio hasta su regreso en primavera. Este misterio tiene como epicentro lo individual, lo apolíneo refiere a la individualidad fenoménica que tiene como patria la esencia. Es por medio del éxtasis que se abre esta esencia al conocimiento dejando atrás la individualidad, este sería el éxtasis que según la tradición tuvo Pitágoras, por el cual pudo percibir la música de las esferas. Esto es a lo que se refiere Giorgio Colli al decir que la filosofía (o sabiduría) tiene como matriz al éxtasis o la locura ( $\mu \alpha v i ́ \alpha)$. Para Colli este tipo de éxtasis se da como una condición previa a la dimensión epistemológica:

"No obstante, el éxtasis mistérico, en la medida en que se llega a él despojándose completamente de las condiciones individuales, es decir, en la medida en que en él el sujeto que conoce no se distingue del objeto conocido, debe considerarse como el presupuesto del conocimiento más que como conocimiento propiamente dicho" (1977, p.15).

Para Suhrawardî y sus seguidores este estado "apolíneo del éxtasis" es el conocimiento por presencia, que será en este caso el elemento central en el ámbito epistemológico. Justamente el centro de los problemas epistemológicos de Suhrawardî se encuentran dos conceptos importantes de su filosofía îshrâqî o iluminativa en los cuales fluye la influencia

6 Platón daba la etimología del nombre Apolo a la palabra

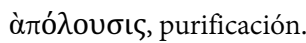

7 " El Hikma al-ishrâq comienza con una crítica densa pero sustancial de la teoría peripatética de la ciencia y la metafísica. Cuando se lee el relato posterior de Suhrawardî del sistema filosófico que presenta como su alternativa a la luz de esta introducción crítica, es difícil no recibir la impresión de que él intenta reemplazar los conceptos peripatéticos intimamente conectados de sustancia y definición con los nuevos conceptos de luz (nûr) y apariencia (zuhûr). Como veremos, la estrategia de Suhrawardî de definir la luz y la apariencia de una manera que sea independiente de estos conceptos fundamentales peripatéticos depende en gran medida del fenómeno de la autoconciencia. Pero para comprender la introducción del nuevo concepto, tenemos que describir brevemente cómo Suhrawardî allana el camino al criticar los fundamentos peripatéticos del ser y el conocimiento. En su discusión sobre el concepto de sustancia, o sustancialidad, Suhrawardî parte de la definición peripatética tal como la transmite Avicena. Según esta opinión recibida, "sustancia" es lo que no existe en un sujeto, independientemente de si es pitagórica: uno es el concepto de "autoconciencia” (شُعور), "autoconciencia insustancial" -shu'ur bi-l-dhat-, el otro se manifiesta en el concepto "conocimiento por presencia" - 'ilm bi-l-hudûr o también llamado "conocimiento presencial" 'ilm hud̂ûî- (علم حضورى). Ambos conceptos surgieron como una mejora en la noética aviceniana, pero al mismo tiempo usando las herramientas de Avicena para explicar cómo uno realmente conoce los detalles en las maneras particulares ${ }^{7}$. El mismo Avicena de las obras más tardías dio importancia a esta vía de obtención de conocimiento, como lo dejó plasmado en su libro "Kitab al-Isharât va al-tanbihat" al afirmar que para entender las verdades se debe caminar el sendero de la intuición, y dejar a un lado el camino de las ciencias adquiridas:

\begin{abstract}
"Y allá existen niveles... que no se pueden entender por palabras, y las palabras no tienen el poder de explicarlos, y no se puede descubrir si no a través de la imaginación. Y cualquier persona que guste conocer de esos grados debe pasar los niveles hasta convertirse en los de la gente de la observación, y arribar a la posición de aquellos que han llegado a la verdad, no como los que sólo hablan y escuchan los efectos." (2016, 3 tomo, 390)
\end{abstract}

Dichos conceptos de la filosofía îshrâqî, como se aprecia, refieren a una metodología para la adquisición de conocimientos y la percepción de la realidad, donde el símbolo de la luz - nûr- (نور) conduce este tránsito epistemoontológico. ${ }^{8}$ Así lo describe el gran investigador de la obra de Suhrawardî, el iraní Hossein Ziai (1944-2011):

totalmente independiente de un sustrato o inherente [en un sustrato], pero el sustrato no es independiente de él como las "formas". Esta definición del Talwîhât contrasta la sustancia con el accidente (al'arad) que existe en un sujeto. También insinúa la división tradicional entre diferentes tipos de sustancias, es decir, materia, forma y su composición. La definición correspondiente en el Hikma al-ishrâq agrega una referencia a la realidad extramental; según él, la sustancia es "algo que tiene una existencia fuera de la mente" y que "no es inherente a otra de modo que se difunde por completo." (Kaukua, J. 2015. Self-awareness in Islamic philosophy: Avicenna and beyond. p.105).

${ }^{8}$ Como parte de los estudios contemporáneos sobre este tópico en Suhrawardî tenemos los análisis sobre el conocimiento "cara a cara"- hִudûrî- del gran especialista iraní Ebrâhîmî Dînânî, el cual realizó un profundo estudio de algunos pasajes de los libros de Suhrawardî relacionados con la concepción de la autopercepción (1998). El investigador japonés Haruo Kobayashi brinda algunas observaciones sobre la noción de autoconciencia desarrollada por Avicena y Suhrawardî introduciendo argumentos desarrollados por 
"La filosofía iluminativa o teosofía oriental, tal como se describe en las obras de Suhrawardî, consta de tres etapas que tratan la cuestión del conocimiento, seguidas de una cuarta etapa de descripción de la experiencia. La primera etapa está marcada por la actividad preparatoria del filósofo: éste tiene que "abandonar el mundo" en las lecturas para aceptar la "experiencia". La segunda es la etapa de iluminación, en la que el filósofo alcanza visiones de una "Luz Divina" (al-nûr al-ilâhî). La tercera etapa, o etapa de construcción, está marcada por la adquisición de conocimiento ilimitado, que es el conocimiento iluminativo (al- 'ilm al-ishrâqî) en sí mismo. La cuarta y última etapa es la documentación, o forma escrita de esa experiencia visionaria. En consecuencia, la tercera y cuarta etapas, como se documenta en los escritos de Suhrawardî, son los únicos componentes de la filosofía de la iluminación, tal como fue practicada por

este último (en sus obras árabes) para demostrar la naturaleza inmediata de la autoconciencia, pero sin proponer un análisis en profundidad de estos últimos argumentos (1990). Esta área concerniente a las dicotomías entre la visión aviceniana e îshrâqî en el tema de autoconciencia, es completada en los estudios de Jari Kaukua, en su análisis de la autoconciencia insustancial (2015) y las nociones meramente dependientes de la mente -i tibârî- en Suhrawardî (2020), igualmente por Roxanne D. Marcotte en su análisis de la identidad personal y la percepción primaria (2006), por Tianyi Zhang, el cual hace un profundo estudio de las argumentaciones e incursiona en temas de la filosofía de la mente (2019), y por Mateus Domingues Da Silva al poner en juego la coimplicación de los conceptos iluminativos -îshrâqî- de presencia y privación de presencia - 'adam al-ġayba- (2019).

${ }^{9}$ El trabajo del filósofo finladés Jari Kaukua aborda la cuestión de la autoconciencia (šu'ûr bi-d̂at) y la naturaleza del yo en la filosofía islámica, partiendo de la idea de que estos temas constituyen una temática por derecho propio. El papel del fenómeno de la autoconciencia en la psicología de autores como Ibn Sînâ, Suhrawardî y Mullâ Șadrâ, así como las preguntas epistemológicas y metafísicas que implica, se analizan sobre la base de varios extractos de trabajos originales de estos autores. Una parte importante del trabajo está dedicada a la forma de concebir el yo y la autoconciencia en el pensamiento aviceniano, a partir de un análisis crítico detallado en particular del "argumento del hombre flotante” de Ibn Sînâ y su papel en la afirmación de la existencia del alma como sustancia inmaterial. La investigación destaca en particular los vínculos entre la cuestión de la autoconciencia en Ibn Sînâ y su psicología dualista que fundamenta la individualidad en la relación de una sustancia inmaterial con la materia, basándose principalmente en el Tratado del Alma del "Shifâ '”, pero también expandiendo el cuerpo de análisis a Išârât, Mubâhațât y Ta'lâqât. El pensamiento aviceniano se enfrenta sucintamente con las críticas a Abû al-Barakât al-Bag̉dâdâ y Faḥr al-Dīn al-Râzî, antes de que sus sucesores aborden su recepción y reinterpretación, esencialmente
Suhrawardî y sus discípulos, a la que tenemos acceso" (1995, 437).

La primera etapa, referida a un método empírico, está marcada por la praxis, a través del retiro y la abstención como preámbulo a la inspiración. Tales actividades caen bajo la categoría general de prácticas ascéticas que buscan la autoconsciencia, aunque no en estricta conformidad con los estados prescritos del camino místico o tarîqah sûfî, como se conoce en las obras místicas disponibles para Suhrawardî en su tiempo. Según Suhrawardî, una parte de la "luz divina" (al-bâriq al-ilâhî) que reside dentro del filósofo, posee potencialidades intuitivas. El investigador Jari Kaukua en su texto "Self-awareness in Islamic Philosophy" (2015)

Suhrawardî y Mullâ Șadrâ. Kaukua establece cómo se toma y se transforma la descripción aviceniana de la autoconciencia que llegará a la metafísica sohravardiana, en particular la definición de los conceptos de conocimiento como presencia (hudûr), y existencia ligera (nûr) o apariencia (Zuhûr). Recurriendo a numerosos extractos de la obra de Suhrawardî, Kaukua destaca la desconexión entre la autoconciencia y la sustancialidad, que se profundizará en la filosofía de sadriana. Esto en Suhrawardî se ve en la diferencia metodológica de textos como "al-Talwîhât", de línea peripatética y "Hikma al-ishrâq" de concepción ishrâqî:

"Del mismo modo, se ha argumentado que en lugar de una culminación del corpus suhrawardiano, las narraciones místicas equivalen a poco más que tratados introductorios diseñados para estudiantes que aún no son capaces de saborear la argumentación técnica y conceptualmente rigurosa propia de las obras filosóficas. No veo ninguna razón para ocultar mi simpatía por la última línea de interpretación. Si las obras peripatéticas hubieran tenido un carácter meramente propedéutico, ¿por qué habría gastado Suhrawardî tanto papel y tinta vital en ellas, en particular en comparación con el volumen decididamente menos imponente de "Hikma al-ishrâq"? De hecho, ¿por qué eligió escribir dos obras introductorias de este tipo cuando el "Talwîhât", por ejemplo, parecería haber sido la única perfecta para la tarea? Además, el trabajo reciente que sitúa a Suhrawardī en el contexto de la recepción de Avicena en el siglo XII ha arrojado algo de luz muy necesaria sobre la cuestión de cómo la discusión en los tratados peripatéticos allana el camino para la transición de Suhrawardî a la filosofía abiertamente ishrâqî del "Hikma al-ishrâq". Dado que el "Talwîhât" y el "Mashâri 'wa al-mutârahât" están comparativamente más cerca del marco terminológico de la filosofía aviceniana, nos brindan una evidencia invaluable para evaluar por qué y en qué medida el "Hikma al-ishrâq" se aparta de esa tradición. Espero que esta postura interpretativa esté ampliamente fundamentada también en los dos capítulos siguientes" (2015.106). 


\section{(iA) DiALEKTILA}

analizando el tema de la autoconciencia insustancial en Suhrawardī, expone esta fenomenología de la luz del filósofo persa:

"Suhrawardī distingue entre dos tipos de luz o apariencia, la luz que es para sí misma (nūr li nafsihi) y la luz que es para otro (nūr li ghayrihi), afirmar que la luz para otro se basa en la luz metafísicamente previa para sí misma. Las dos luces están relacionadas jerárquicamente por dos razones. En primer lugar, el otro al que aparece la luz para otro tiene que aparecer ante sí mismo o ser consciente de sí mismo para poder aprehender la aparición de una luz distinta de sí mismo. Suhrawardī es inequívoco sobre este requisito: "Lo que no tiene conciencia de sí mismo no es consciente de otro (lā yash 'uru bi ghayrihi man lā shu'ūra lahu bi dhātihi). Pero lo que es más importante, nada puede parecerle a otro a menos que primero se le aparezca a sí mismo. En otras palabras, la luz que aparece a otro es causada por una luz que se le aparece a sí misma, o, formulado de una manera más precisa, es la apariencia externa de algo que es pura apariencia en y para sí mismo." $(2015,106)$

Por lo tanto, al practicar las acciones de la primera etapa se puede, a través de "revelación personal" y "visión" (mushâhadah wa mukâshafah), aceptar la realidad de su propia existencia y admitir la verdad de su propia intuición. Por eso, la primera etapa consiste en: 1ro. Una actividad. 2 do. Una condición o potencialidad que todos cumplen, ya que se nos dice que cada persona tiene intuición, y en todos hay una cierta porción de la luz de divina (Esta etapa tiene cierto parangón con el simbolismo de la salutación oculta de los pitagóricos en su emblema de la estrella de cinco vértices o pentagrammon, símbolo solar que codificaba la frase $\alpha u ́ \gamma \varepsilon \dot{\varepsilon}$ عĩ : ¡Ánimo [hacia, a] la luz!). 3ro. Una "revelación” personal a través de la autoconsciencia.

En este ámbito estaría la utilización de lo mistérico o el secreto como vía pedagógica, a partir de una enseñanza por medio de una epifanía. Tanto Pitágoras como en Suhrawardî, la enseñanza a través de la manifestación de una epifanía está presente, en Pitágoras con Orfeo, en Suhrawardî con Hermes y con un Aristóteles platonizado. El mismo Suhrawardî deja

Los capítulos a los que hace mención, el VII (Mullā Sadrā on selfawareness) y el VIII (The self reconsidered: Sadrian revisions to the Avicennian) los dedicarán J. Kaukua a la forma en que Mullâ Șadrâ reinterpretó el argumento de Ibn Sînâ, convirtiéndose la autoconciencia en una forma de existencia o un modo de existencia mental (wujūd dihnī) dentro del marco de su sistema metafísico basado en la primacía o fundamentalidad de la Existencia (isāālat al- constancia de esta epifanía, en la frontera de lo onírico, con el alma de Aristóteles en su libro "Talwihât al-Luwhiyyati va al-arshiyyat" o "Libro de las Elucidaciones" en el cual relata lo siguiente:

"Hubo un tiempo en que tuve muchos conflictos mentales, y en esa época la cuestión del conocimiento se me tornó difícil, lo que existía en los libros no podía resolver el problema pues no era claro para mí. En una noche entre el sueño y la vigilia tuve un dulce acontecimiento, vino a mí una fuerte luz acompañada de una sombra humana; lo que vi en el sueño era nada más y nada menos que el Ayudante de las Almas, el Líder de la Sabiduría, el Primer Maestro. Me maravilló pues emanaba gran magnanimidad, se colocó frente a mí calmando mi miedo. Me dijo: Vuelve en ti y tu problema será resuelto. Pregunté: ¿Cómo? Dijo él: Acaso la percepción que tienes de ti mismo es un conocimiento directo que posees a través de ti mismo o se debe a algo distinto de este." (2015, 423-424)

El relato de la epifanía o visión onírica de Aristóteles a Suhrawardî se da como una alegoría a través de la cual el filósofo persa ejemplifica su propia visión del conocimiento. Esta narración tiene una serie de componentes característicos que pueden analizarse brevemente de la siguiente manera. En primer lugar, en la visión, que es un estado acompañado de un placer abrumador (ladhdhah), destellos (barq) y una resplandeciente luz, se afirma que es una de las etapas intermedias de la experiencia visionaria iluminista, Aristóteles, el "Primus Magister" (المعلّم الأوّل) y “Ayudante de las Almas” (غياث النفوس), se le aparece a Suhrawardî, quien hace una pregunta concerniente al conocimiento (mas'alat al-ilm), cómo se obtiene, de qué está hecho y cómo se reconoce.

La respuesta de Aristóteles es: "regresa a tu alma - o vuelve en ti -” (ارجع نفسى فنتحلّ لى). El autoconocimiento es un componente fundamental de la teoría ishrâqî del conocimiento. El conocimiento como percepción del alma es esencial y auto constituido, porque un individuo es consciente de su esencia por medio de esa esencia misma. La autoconciencia y el concepto del "yo" - el yo como yo, o su

wujūd). La autoconciencia surge aquí del monolitismo estático de la sustancia, para convertirse en una realidad modulada cuyos atributos conocen una evolución perpetua de acuerdo con su interacción con el mundo exterior. 
ipseidad, su ser - son los fundamentos del conocimiento. Lo que se gana en última instancia a través de la conciencia inicial de la propia esencia es una forma de conocimiento, denominada la "ciencia basada en la presencia y la visión" (al-'ilm al-hudûrî al-shuhûdî). Para Suhrawardî, este es un tipo de conocimiento mucho más alto que el obtenido por los filósofos peripatéticos o mashầ $\hat{\imath}$, que confían en la unión con el intelecto activo. En el mismo relato de la epifanía se da una crítica a la vía de obtención de conocimiento filósofos y una validación de método de los místicos:

"Y entonces comenzó a alabar a su maestro Platón el Divino, algo que me extasió. Le pregunté: ¿acaso entre los filósofos musulmanes hay alguien parecido a Platón? Él dijo: No, y ni llegan a la división en mil partes de Platón. Nombré algunos filósofos, pero no hizo caso, mencioné entonces a místicos como Abu Yazîd al Bastâmî, Abu Muhammad Sahal Ibn Abdullah Tustarî y otros como ellos, se mostró alegre al escuchar estos nombres y dijo: Ellos son filósofos y sabios verdaderos, que no se contentaron con el conocimiento aparente, sino que fueron al conocimiento intuitivo. Me dijo que ellos no se han ocupado de asuntos materiales (...), ellos caminaron en nuestros caminos y hablaron lo mismo que hablamos nosotros." (2015, 430-431)

Esta crítica a la vía de los filósofos está dirigida a los peripatéticos o corriente mashâ' $\hat{\imath}$, paradójicamente en boca de un Aristóteles que proclama el shuhûd (الثهود) o intuición mística como verdadera vía, según lo relata Suhrawardî. Esta platonización del Aristóteles del relato podría darse en el sentido de la lectura del texto "Uthûlûjiyâ" o la llamada “Teología” adjudicada erróneamente a Aristóteles, y que no es más que una traducción al árabe de fragmentos de los capítulos IV al VI de las “Enéadas” de Plotino, pero integrado con los comentarios de su discípulo Porfirio de Tiro (234305) y elementos de la teología de Proclo.

Retomando las etapas descritas por Suhrawardî, pasamos a la segunda de este método, donde la ascesis lleva a una experiencia con la luz divina. Esta luz luego toma la forma de una serie de "luces de la realidad última" (al-anwâr alsânihah), y a través de ellas se obtiene el conocimiento que sirve de base para las ciencias reales (al- 'ulûm alhaqîqiyyah). Hossein Ziai en su monografía "Shihâb al-Dîn Suhrawardî: founder of the Iluminationist school" (1995) describe cómo se da el contacto con este estado de luz divina:

“La iluminación es también el principio mediante el cual se regula el movimiento celeste. La iluminación se propaga de la Luz de Luces al nivel humano por medio de ciertos principios intermedios. Estas son las "luces controladas" (al-anwâr al-ghâhirah) y las "luces eficientes dirigidas" (al-anwâr al-mudabbirah). Entre estas últimas, las principales luces que afectan directamente al alma humana son las luces isfahbad. La Luz de Luces lo controla todo. Es más evidente para sí mismo y, por lo tanto, es el ser más consciente de sí mismo en el Universo. Todas las luces de los resúmenes se iluminan directamente con la Luz de las Luces, cuya luminosidad (nûriyyah), esencia (dhât) y potencia son todas una y luego la misma. La Luz de las Luces es autoemanante, y sus atributos y esencia son uno. Cuando las "iluminaciones celestiales" (al-ishrâqât al- "ulwiyyah) alcanzan al alma humana a través de la intervención de las luces isfahbad, todo el conocimiento se da a la persona. Tales momentos son las visiones de las luces apocalípticas, que son el fundamento de la experiencia visionaria, y los medios para obtener conocimiento sin restricciones. Las almas humanas que han experimentado las luces apocalípticas se llaman "almas separadas de la materia" (al-nufûs al-mujarradah), porque se han desprendido de la esclavitud física del cuerpo. Obtienen una "idea de la luz de Dios" (mithâl min nûr Allâh), que la facultad de la imaginación imprime en la "tabla del sensus communis" (lawh al-hiss almushtarak). Mediante esta idea, obtienen el control sobre una "luz creativa" (al-nûr al-khâliq) que en última instancia les da poder para saber. El momento de iluminación que experimentan los Hermanos de la Separación de la Materia y los Maestros de la Visión (ashâb al-mushâhadah), es descrito por Suhrawardî como una experiencia gradual de "luz" en quince pasos, comenzando con la experiencia de la "luz de placer intermitente" (al-nûr al-bâriq al-ladhîdh) y terminando con la experiencia de una luz tan violenta que puede desgarrar el cuerpo de las articulaciones." $(1995,455)$

El arribo a esta Luz de Luces debe darse por la mediación de las luces dominantes o îsfahbad, que actuarán como una especie de "causación vicaria" para que se dé la apertura de conocimiento del hombre a la Luz de las luces, es, dicho en términos griegos, el Kairós donde acontecerá el Aión en su repliegue de los límites. Sobre esta luminosidad intermedia dice Suhrawardî en "Hikmat al-ishrâq":

"La luz dominante (îsfahbad) invoca la constitución intermedia en virtud de su capacidad para hacer que esa luz exista, ella tiene filiación con su fortaleza pues dicha fortaleza la ha llamado a su existencia. Su relación con el cuerpo (el mundo material) se debe a su pobreza en sí misma y su contemplación a lo que está encima de ella (la Luz de luces) se debe a lo que de luminosidad hay en ella." (2015, 328)

La tercera etapa, ya dentro de método teórico, es la fase para estructurar una correcta ciencia ('ilm sahîh). Es durante este periodo que el filósofo hace uso del análisis discursivo. La 


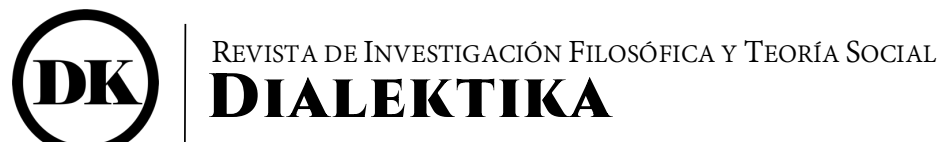

experiencia se pone a prueba, y el sistema de prueba utilizado es la demostración (burhân) aristotélica del texto "Analíticos Posteriores". Ziai comenta al respecto:

\begin{abstract}
"La misma certeza obtenida al pasar de los datos de los sentidos (observación y formación de conceptos) a la demostración basada en la razón, que es la base del conocimiento científico discursivo, se dice que prevalece cuando se "demuestran" los datos visionarios sobre los que se basa la filosofía de la iluminación o teosofía oriental. Esto se logra a través de un proceso de análisis destinado a demostrar la experiencia y la construcción de un sistema en el cual se pueda colocar la experiencia y validarla, incluso después de que la experiencia haya finalizado" $(1995,438)$.
\end{abstract}

El impacto de la teoría del conocimiento específicamente iluminativa, generalmente conocida como "conocimiento por presencia" (al- 'ilm al-hudûrî), no se ha limitado a los círculos filosóficos y otros ambientes especializados, como lo ha sido, por ejemplo, la lógica iluminativa. El estado epistemológico dado al conocimiento intuitivo ha influido fundamentalmente en lo que se denomina en Persia "misticismo especulativo o teórico" ('irfân nazarî), aspecto investigado profundamente en la actualidad por Seyyed Yazdânpanâh (2016). El paradigma implica un sujeto (mawdîu'), la percepción (idrâk) en el sujeto, así como su relación con él, y la realidad creada concreta (khallâqiyyah). La transición del sujeto (al-mawdî̀') al sujeto conocedor (al-

\footnotetext{
${ }^{10}$ Dentro de este tipos de relatos visionarios poéticos- filosóficos de Suhrawardî se encuentra "La navegación en el navio de Noé", segunda historia dentro del "Relato del exilio occidental", el cual guarda estrecha relación con toda una estela de simbologías tradicionales contenidas en el logos poético- espiritual, éste tiene para sí un grupo de elementos simbólicos referidos al viaje (hacia la divinidad), donde las figuras del arca, la desesperación ante las zozobras (del viaje) y la montaña cósmica como fin y nuevo principio del viaje son concurrentes en esta poética espiritual. (Otros elementos como la lámpara, los astros, el dragón y la joya son contemplados en el abanico de la simbología tradicional que bebe de los libros revelados). Dichos elementos son, en este caso, contrapunteados bajo una hermenéutica ( $\left.t a^{`} w \hat{\imath} l\right)$ de los versículos coránicos, donde obviamente el espejo referencial en que se mira este relato es la historia bíblica y coránica del Profeta Noé o Nûh. Es conocido que el mitologema de la travesía marítima posee una profunda carga simbólica en los diferentes contextos culturales humanos, piénsese desde el mito de la barca de Ra, el mito de los argonautas, Odiseo, hasta las leyendas escandinavas, polinesias e indo-caribeñas sobre este elemento. Otra influencia tenida por Suhrawardî viene de las obras sufíes del persa 'Attâr de Nishapûr, la
}

mawdî'al-mudrik) y al sujeto creador de conocimiento (almawdîu al-mudrik al-khallâq) marca la transformación del ser humano como sujeto en un estado natural, al sujeto del saber en el primer estado donde el conocimiento trasciende el conocimiento simple y comienza el viaje espiritual. Esto conduce finalmente al estado de unión, cuando el sujeto que conoce entra en los dominios del poder (jabrût) y lo Divino (lâhût), y el ser humano obtiene la realidad (haqîqah) de las cosas, a partir de una realidad fuerte (înniyyat) y se convierte en el sujeto que crea el conocimiento. Lo que finalmente se crean son "poemas". Los pitagóricos daban a la palabra la capacidad de evidenciar tres niveles que hacen manifiesto la realidad del Universo. Estas tres dimensiones: expresividad, ocultamiento y signo, se condensan en la unidad poética integrada a un sistema filosófico cuyo denominador es el relativismo y su categoría central, el Kairós, lugar de acontecimiento del Aión. Según los pitagóricos el logos poético es resultado del contacto con la intuición primordial en un cosmos total de coexistencias, es la narración sobre la esencia experimentada, la que sería la cuarta etapa del método de Suhrawardî, la articulación de un relato visionario poético-filosófico, muy por el estilo de los poemas filosóficos-oraculares de Anaximandro, Heráclito, Parménides, Empédocles y los apócrifos “Versos áureos” de Pitágoras ${ }^{10}$.

cual es evidente desde el primer momento del relato. La navegación en el arca se constituye en la travesía del microcosmos al macrocosmos, donde está el Sinaí místico (la montaña de Qaf en el caso del grupo de aves en el poema de 'Attâr). Sus etapas, a decir de Henry Corbin: "serán la interiorización progresiva de los elementos y los cielos de la astronomía física, estarán marcadas por los versículos coránicos y serán transmutadas por la hikâyat en imágenes del mundus imaginalis." (Corbin, H. 2002. "El encuentro con el ángel. Tres relatos visionarios"). Esta obra fue escrita como sentencias espirituales en versos, lo que la incorpora al estilo de creación poética-filosófica afín a Pitágoras, Anaximandro, Heráclito y Parménides de poesía didâshkalîka. En ocasiones estos versos se tornan herméticos por la densidad de sus símbolos, de ahí que sea necesario una hermenéutica correlativa para verter claridad en ellos. Para el lector de poesía hispana, este texto le traerá reminiscencias con Lezama Lima, el cual quizás no leyó a Suhrawardî (Lezama pudo tener alguna referencia del teósofo de las luces por medio de la filósofa y poetiza María Zambrano, la cual fue discípula de Louis Massignon, y por lo tanto pudo conocer las investigaciones del otro gran discípulo de Massignon, Henry Corbin), pero en su poesía existe un eco suhrawaniano que puede venir del platonismo y del 


\section{ALMA, IPSEIDAD, REALIDAD}

En este punto, habiendo repasado la epistemología îshrâqî y los vasos comunicantes en ella con el pitagorismo, es menester que se destaque uno de los términos de la filosofía ishhrâqî de mayor complejidad, tanto para su significación en lengua árabe como para su traducción a otras lenguas. Este es el vocablo técnico înniyyat (الإنيّة), el cual muchas veces se le transcribe fonéticamente, de manera equívoca, como ânniyyat. Como parte de la epistemología y la ontología de Suhrawardî înniyyat cumple un rol fundamental como parte del conocimiento por presencia, puesto que la inniyyat desempeña varios sentidos que se denotan en la esfera ontológica tanto a una realidad del ser o realidad firme, la hecceidad (haecceitas) o estidad, como también refiere a la ipseidad y esencia.

El místico persa de gran influencia îshrâqî Kamâl al-Dîn 'Abd al-Razzâq al-Kâshânî (1334-1351), en su texto "Tahlîyat alArwâh Bihaqâ íq al-injâh" expone el argumento del "hombre volador o del hombre suspendido" de Avicena, utilizando el término înniyyat:

"No posees el recuerdo de cómo tu esencia estuvo presente en todos los tiempos para ti, no puedes ocultarte de tu esencia en ninguno de los instantes, ya sea cuando estas despierto o ebrio, ya sea cuando estas dormido o cuando estas entre la vigilia y el sueño. Y si conjeturaras que tu alma hubiese sido creada de repente con su perfección intelectiva suspendida en el aire, de modo no lograras tocar tus miembros, no utilizaras tus sentidos y no poder realizar ningún movimiento ni pausa, entonces encontrarás tu esencia sin ninguno de tus miembros ni ningún accidente. En esta situación tendrás conocimiento con respecto a tu esencia y de cómo esta no es densa necesariamente; porque tu conjuración está en ocultar todas las cosas, excepto su realidad firme (înniyyat). Lo oculta cuando estás presente con tu esencia no tiene ninguna relación con la misma. (...) Y también: Alguna vez puedes olvidar cada uno de tus partes, y no recuerdas ninguna cosa de ellas que haya sido añadida una vez o dos veces, y no encontrarás su multiplicidad (de partes) sino por una descripción. Pero

neoplatonismo del poeta cubano; lográndose la percepción de "azares concurrentes" entre sus cosmovisiones poéticas espirituales.

${ }^{11}$ Este argumento no está respaldado por el concepto de sustancia en metafísica. Este campo experiencial muestra que el yo no es, en consecuencia, una sustancia y, por lo tanto, no hay subjetividad. Por otro lado, algunos eruditos como Wisnovsky creen que el argumento del hombre volador demostró la sustancialidad del alma. es imposible que su realidad firme (înniyyat) desaparezca en ningún instante; la realidad firme (înniyyat) es distinta a las partes." (2005, 107-108)

Este argumento, que ya se vio anteriormente en voz del Pitágoras citada por Shams al Din Muhammad alShahrazûrî, se basa en un experimento mental introspectivo ideado por Avicena en su cautiverio en el castillo de Fardaján, en la provincia iraní de Hamadán. Este experimento tiene como fin demostrar que el alma es inmaterial y sustancial, y que el hombre no puede negar su propia conciencia y conocimiento. Según Avicena, el hombre suspendido podría alcanzar el concepto de ser sin ninguna experiencia sensorial. al-Razzâq al-Kâshânî retoma este argumento donde conjetura sobre cómo alguien podría accidentalmente llegar a existir completamente desarrollado y formado, pero sin tener ninguna relación con la experiencia sensorial del mundo o de su propio cuerpo y sus partes. Según al-Razzâq al-Kâshânî siguiendo el argumento de Avicena, este sujeto es, sin embargo, necesariamente consciente de sí mismo. En otras palabras, tal ser posee la conciencia de su propia existencia. Por lo tanto, cree que el alma tiene un conocimiento reflexivo e inmediato de su propia existencia, de su înniyyat. Apelando así a la autoconciencia, al-Razzâq al-Kâshânî intenta probar la existencia del alma o nafs, y el grado intensivo de la înniyyat. ${ }^{11}$

Es importante distinguir înniyyat (الإنيّة) de otro término muy usado por Suhrawardî y su escuela, este es ânâ îyyah (انائيّة), que parte del pronombre personal ânâ (انا), yo, por otro lado, el término înniyyat es una palabra formada por la partícula de aseveración înna (إنّ), “ciertamente” que pertenece a las partículas semejantes por acción. Por ello fonéticamente debe pronunciarse como înna. Se puede decir que una denota al sujeto de conocimiento y otra al objeto del mismo.

Suhrawardî al usar el pronombre ânâ (انا) como representación al yo distintivo o al ego, que propicia la autoconsciencia dice.

Avicena cree que la conciencia innata es completamente independiente de la experiencia sensorial. El investigador Muhammad Faruque, en su "Sculpting the Self: Islam, Selfhood and Human Flourishing" (2021), ha desarrollado un estudio comparativo con el argumento de Avicena y las teorías de autopercepción y subjetivismo de la literatura filosófica contemporánea. 


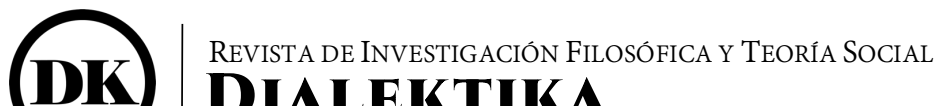 DIALEKTIKA}

”.انا..شيئ ادرك ذاته،

$(2014,116)$

"Yo (ânâ) ...soy algo que percibe su esencia".

Con respecto a ânâ'îyyah (انائيّة) es utilizada frecuentemente por Suhrawardî en su libro "Hikmat al-ishrâq" (Sabiduría oriental) como una forma diferente de la abstracción:

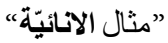

$(2014,3)$

“Ejemplo de la egoidad (ânâ'îyyah)."

Del mismo texto usa:

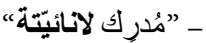

$(2014,403)$

"Perceptivo [conocedor] de la egoidad (ânâ'îyyah)."

Suhrawardî escribe en el mismo texto:

"Se ha demostrado que tu ego (ânâ'îyyah) es una luz incorpórea, que es consciente de sí mismo y que las luces incorporales no difieren en sus realidades. Así, todas las luces incorpóreas deben aprehender sus propias esencias, ya que lo que es necesariamente cierto de una cosa debe serlo también de lo que tiene la misma realidad" $(2014,466)$.

De este modo, el filósofo distingue el "objeto de cognición” del "sujeto", este último encarnado en el "yo" (ânâ'îyyah) acuñado por Suhrawardî para identificar el "modo de ser propio de un sujeto cognitivo"; la autoconciencia, como mera aprehensión y existencia, se distingue ahora de la conciencia de objetos separados.

Pero en el caso de înniyyât, correspondiente al griego tò

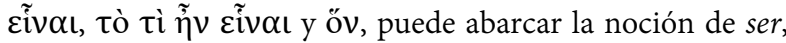

\footnotetext{
${ }^{12}$ Estas distinciones dentro del término realidad están presentes en los términos árabes înniyyât y haqîqat en el terreno filosófico. Se establece, al mismo tiempo, una coimplicación en los términos filosóficos haqîqat, haq y wâq'iyyat. El término haq o verdad (حق), que aparece en el Corán (3-80), posee diversos usos en dependencia del campo, pero en filosofía tendrá la referencia a la verdad, y así se tradujo del griego el término $\dot{\alpha} \lambda \eta \dot{\theta} \theta \varepsilon \iota \alpha$ de los textos aristotélicos (Metafísica 999 30). El término wâq iyyat o realidad de las cosas (واقعيّت), refiere a lo que “es” en un estado extramental y en un perpetuo presente, en ese sentido de definir la realidad de las cosas y de su carácter extramental, posee un gran paralelismo con inniyyât. Por otro lado, haqîqqat o realidad (حقيقت), posee un estado
}

realidad firme, sustantivo, concreto existente o esencia particular, o idea arquetípica, dependiendo de si el autor está inspirado en la tradición aristotélica o neoplatónica. Este significado de înniyyât como realidad firme e independiente, es utilizada por parte de Suhrawardî con este sentido. Dice Suhrawardî en un fragmento de su libro "Hikmat al-ishrâq":

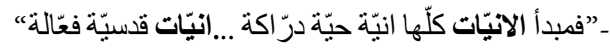

$(2014,54)$

"El origen de todas las realidades (al-înniyyât) es una realidad viva (înniyyat hayyat) que sobre-percibe las realidades trascendentes activas".

En otro fragmento de su texto "Hikmat al-ishrâq" dice:

“انيّت و هويّت

$(2014,76)$

"Realidad (înniyyat) y entidad (huwiyyat)".

Esta distinción de Suhrawardî entre înniyyat (الإنيّة) y huwiyyat (هويّة) debe explicarse en el sentido de que huwiyyat, "entidad" del ser; esto es, su "realidad" o haqî́qat (حقيقة), refiere a las realidades existenciales concretas, a las ipseidades intrínsecas. Asimismo, inniyyat designa al ser mismo de una cosa, la haecceitas de algo. Estas variantes no se deben a deficiencias lingüísticas sino a la intrínseca falta de concreción del problema del ser, lo que motiva el tránsito de términos que intentan definir los ámbitos del acontecer ontológico Si bien en árabe existe el término realidad como haqîqat (حقيقة), éste difiere en el sentido de realidad que brinda înniyyât. Como término filosófico haqîqat refiere en buena medida a un sentido modal, cercano a términos como actualidad-f' $f^{\prime} a l$-(فعل) o efectividad - fa'iâlia -(فعالية). ${ }^{12}$

atemporal. Allí donde haq refiere a lo real o la verdad, wâq'iyyat refiere a la esencia de las cosas y a su verdad y por último haqîqat se presenta como coimplicador o vicario entre haq y wâq'iyyat, el primero en función concordante y el segundo como concordado. El término haqîqat posee una estructuración de significados varios: la primera es la realidad (haqîqat) con significación de la esencia, la cual está en oposición a lo convencional o relativo ( $i^{\text {‘ }}$ itibâr ), es decir, aquello que refiere a los asuntos convencionales (حقيقت مُقابِل اعتبار). La segunda refiere a la realidad en oposición a lo hipotético o lo supuesto (حقيقت مقابل فرض), que coincide con lo real mismo o el orden mismo, llamado nafs-ul âmr (هف الامر). El tercero manifiesta la realidad en oposición a lo conceptual o mafhûm 
Para Suhrawardî el objeto de conocimiento está en esa realidad fuerte, la Luz primera (la Luz de luces), que propone el término înniyyât que podríamos estructurar en cinco sentidos coimplicados:

La realidad pura (الإنيّة الصرفة) referente a la existencia pura (الوجود الصرف), la realidad simple o indivisible (الإنيّة البسيطة) equivalente a la existencia simple (الوجود البسيط), la Realidad Primera (الإنيّة الاوّلى) referente a la existencia necesaria (الوجيط) (الوجود), la realidad o la existencia [ الإنيّة (الوجود), referida a la realidad de la existencia (حقيقة الوجود) y la realidad o existencia

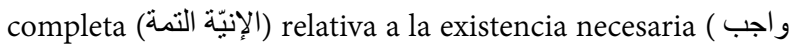
(الوجود).

En el caso de la realidad simple o al-înniyyat al-basittat (الإنيّة البسيط (البسيطة (البية), refiere la realidad indivisible verdadera (الحقيقى), que ofrece relación con los conceptos indivisibles puros (البسائط البحتة), indivisible primero (البسيط الأول), la verdad indivisible (البسط الحق), indivisible de modo absoluto (البسيط على الإطلاق), indivisible por todos sus aspectos o formas (البسط من جميع الجهات) e indivisible absoluto (البطيط الاتليط (المطلق).

En la obra "Kitâb al-Lamahât”, Suhrawardî expresa:

"الحقيقة البسيط ما لبس فيه جعلان أصلاً"

$(2015,170)$

"La realidad simple es [aquella] en la que no se encuentra en ella una instauración originada".

Es por ello que înniyyât refiere a la luz primera (النور الأوّل) o la luz completa (النور التام), en la cual se aprehenderá el conocimiento inmediato, sin mediación material y "cara a cara", un estado donde se anula cualquier distinción entre objeto y sujeto. Hay aquí, por decirlo en estos términos, una desmaterialización de la percepción. Para Suhrawardî esta realidad pura, a su vez, realiza la aprehensión de Sí misma, una aprehensión siempre activa que es la emanación misma con todas las cosas emanadas, que es oscilación y refiere a una especie de gran respiración, es aquello que los pitagóricos

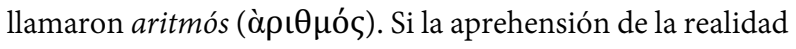
(Luz de luces) a sí misma es activa, entonces la aprehensión

(حققت مقابل مفهوم). Y por último la realidad en oposición a lo metafórico o mayâz (حقيلت مقابل مجاز).

Pero en el sentido de quiddidad existente se ha usado indistintamente en tres maneras como: la realidad de cada cosa en

D I A LEKTIKA • 2022,4 ( 9): 28 - 46.

ISSN 2707-3386 específica de otras luces puras es pasiva y requiere que cada luz intensifique su realidad como un ser aprehensor.

A decir del filósofo Jari Kaukua en su artículo "I'tibârî Concepts in Suhrawardî: The Case of Substance:

"La noción central ishrâqî de luz pura, como la de las formas platónicas, se describe como "luz en sí misma y para sí misma" (fĩ nafsihi li-nafsihi), mientras que la luz accidental es luz en sí misma, pero para los demás (Iighayrihi). Así, las luces accidentales están ahí sólo en la medida en que haya un sujeto distinto de la fuente de esa luz que pueda percibirlas. La metafísica de ishrâqî es, por tanto, una especie de fenomenalismo. Pero para ser una alternativa viable a la metafísica de la sustancia aviceniana, debe poder salvar las intuiciones que corroboran esta última. Si tuviera que fundar la metafísica de nuevo en un concepto fenomenal como 'aparición', una forma poderosa de convencer a sus lectores peripatéticos sería acomodar su punto de vista en su nuevo sistema, particularmente si se percibe que ese punto de vista se desempeña especialmente bien en términos de nuestra ontología cotidiana de sustancias robustas. Quiero sugerir que es este tipo de explicación reductiva de la que depende la filosofía ishrâqî de Suhrawardî: sí, la metafísica peripatética describe acertadamente el mundo tal como nos aparece, sólo que no debemos confundir esa apariencia con los fundamentos de la realidad. $(2020,65)$

Esta singular visión sobre la asociación entre realidad y aprehensión, explicada en términos de manifestación y luminosidad (y en la cual late un pitagorismo subterráneo), desde la perspectiva filosófica es extraordinaria, ya que rompe con la epistemología peripatética hylemórfica, la cual sólo puede dar cuenta y explicar una percepción de uno mismo en términos del intelecto.

\section{LEGADO PITAGÓRICO ÎSHRÂQÎEN MULLÂ ȘADRÂ}

Dentro de los filósofos persas que asumieron el legado pitagórico îshrâqî se encuentra Mullâ Șadrâ, el cual, si bien se opuso críticamente a la teoría de la reminiscencia o anamnesis (ávó $\mu \nu \eta \sigma \iota \varsigma)$ de Platón y de la escuela îshrâqî y, como se expuso previamente, a la teoría del tanâsukh o metempsicosis, desarrolló en su sistema el tema del

el orden de originalidad y realización en ella, la realidad de la existencia en su orden de perfección y la realidad del alma humana. 


\section{DiALEKTIKA}

autoconocimiento suhrawardiano de herencia pitagórica. El objetivo de Șadrâ en su sistema es proporcionar una explicación completa de la naturaleza y los orígenes de la Realidad, que, en la tradición donde se sitúa su pensamiento, se traduce en términos de una explicación de la relación entre un Primer Principio y todo lo que no sea él mismo y del lugar del hombre en el universo y su percepción de la realidad.

El investigador Muhammad Faruque en su texto "Sculpting the Self: Islam, Selfhood, and Human Flourishing" (2021) expone el análisis de Șadrâ sobre el autoconocimiento y la realidad. A decir de Faruque, Mullâ Ṣadrâ dirige su atención a la conciencia y sus modalidades, que corroboran aún más el autoconocimiento de sí mismo. Comienza afirmando en su texto "Mafâtih al-gayb" o "Las llaves del Mundo Invisible" que el yo (al-nafs) "no es un cuerpo, y que tiene autoconciencia [shâ 'ira bi-dhâtihâ]" (2018/2-818). ${ }^{13}$

Es decir, la autoconciencia no es física y es distinta de la conciencia corporal. Luego se distingue entre la autoconciencia de primer orden y la de segundo orden. Șadrâ en su obra cumbre "Al-Hikma al-muta 'âliya fî l-asfâr al'aqliyya al-arba'a" o "La filosofía primera. Acerca de los cuatro viajes del intelecto" expone este punto:

"Nuestro conocimiento de nosotros mismos es el mismo que la existencia de nosotros mismos ('ilmunâ bi-dhâtinā nafs wujûd dhâtinâ), mientras que nuestro conocimiento de nuestro conocimiento de nosotros mismos ('ilmunâ bi-'ilminâ bi-dhâtinâ) es distinto de nuestra propia existencia y es una forma mental (șûra dhihniyya) añadida a él. Esta forma mental no es equivalente a nuestra identidad personal (huwiyyatinâ al-shakhșiyya); más bien, tiene una identidad mental diferente. De manera similar, nuestro conocimiento de nuestro conocimiento de nosotros mismos por medio de este conocimiento es una forma agregada a las dos identidades anteriores del conocimiento (huwiyyat al'ilmayn)." (2018, 3: 321)

Siguiendo lo anterior, Faruque expone como Șadrâ discierne dos niveles distintos de autoconciencia. Para empezar, se puede tener conocimiento de mí mismo en términos de proposiciones de primer orden como "tengo dolor" o

\footnotetext{
${ }^{13}$ Mullâ Șadrâ habla sobre la autoconciencia en varios lugares; véase, por ejemplo, Asfâr, 4: 222, 8: 77-79, 265, 395; y Ta 'lîâ̂t li-Sharh Hikmat al-ishrâq, en al-Hikma al-ishrâqiyya: Majmû'ah-yi mușannafât-i Shihâb al-Dîn Yahyâ al-Suhrawardî. Véase también a Jari Kaukua y su exposición sobre la autoconciencia en Mullâ Ṣadrâ en "Self-Awareness in Islamic Philosophy", 161-191.
}

simplemente "estoy". Debe notarse que en tales proposiciones el sujeto y el predicado son uno y el mismo (Nótese que las proposiciones de primer orden todavía están en el ámbito de la reflexión, mientras que el estado real del dolor, en el que el sujeto y el predicado son uno y el mismo, ocurre antes de la reflexión). Es decir, cuando "tengo dolor" o cuando "simplemente soy", mi ser en "dolor" o mi ser "yo" es inseparable de mi existencia. Por esta razón, Șadrâ afirma que en tales casos la existencia es idéntica al autoconocimiento, o el conocimiento del yo es lo mismo que la existencia del yo, que, en el nivel no reflexivo, no implica una dicotomía sujeto-objeto. Sin embargo, tal ejemplo de autoconocimiento es diferente de un reflejo de segundo orden del autoconocimiento. ${ }^{14}$

En otras palabras, 'ilmunâ bi- ílminâ bi-dhâtinâ (nuestro conocimiento de nuestro conocimiento de ...) es diferente de simplemente 'ilmunâ bi-dhâtinâ (nuestro conocimiento de nosotros mismos). Esto se debe a que una el reflejo del autoconocimiento implica una forma mental (șûra dhihniyya) que se añade a nuestra verdadera identidad, en la que el conocimiento y la existencia del yo son uno y lo mismo.

Dice Muhammad Faruque al respecto:

"Pero como nuestro yo es capaz de tales acciones
reflexivas, sigue siendo parte de nuestra identidad,
aunque diferente. Más interesante aún, tal acto reflexivo
de autoconciencia se puede realizar indefinidamente, en
cuyo caso continuará agregando más "identidades" en
forma de "Tom 1, Tom 2, Tom 3 ... y así sucesivamente"
a nuestra identidad primaria. Esa es la razón por la que
Șadrâ sostiene que nuestra autoconciencia del yo nunca
es idéntica a nuestro yo, ya que las declaraciones
secundarias son sobre el yo y no sobre el yo mismo:
"Además, nos percibimos a nosotros mismos a través de
nosotros mismos porque nunca estamos ausentes de
nosotros mismos. Pero nuestra autoconciencia del yo
(ammâ shu ûrunâ bi-shu ûri dhâtinâ) nunca es idéntica a
nuestro yo, al igual que cuando percibimos cosas
externas a nosotros" [ Mullâ Șadrâ, Shawâhid, 253]. Es
decir, no puedo estar ausente de mí mismo porque mi
realidad como conciencia simpliciter está siempre
presente para mí a través de la ininterrumpida

${ }^{14}$ Mullâ Șadrâ hace todo lo posible para aclarar la conexión entre el yo y el autoconocimiento en términos de autoconciencia; véase, por ejemplo, Asfâr, 1: 134-135; 3: 408, 435-436, 501-506; 4: 458-464; 8: 50-51, 70-79, 151; Mafâtîh, 2: 818, 836, 851-852, 854-855, 939944, 1003, 1083. 
conciencia de mí mismo que es indistinguible de mi (conciencia) "mía”. (2021, 114)

Se puede apreciar que para Mullâ Șadrâ el autoconocimiento en el sentido de autoidentificación es diferente de un reflejo de segundo orden del autoconocimiento. Este último es representación y no es idéntico a la realidad misma del yo.

Mullâ Șadrâ en su texto "Al-Shawâhid al-rubûbiyya fi lmanâhij al-sulukkiyya" o "Testimonios de la Soberanía divina relativos a la senda de la realización espiritual”, donde utiliza un lenguaje îshraqî, proporciona otro argumento al analizado por Faruque, para demostrar cómo la autoconciencia del yo es diferente de la conciencia no reflexiva de primer orden del yo:

"La percepción de una cosa implica la obtención de su forma al que percibe, y quien se percibe a sí mismo (man adraka dhātahu) debe estar separado de su sustrato (es decir, el lugar de percepción). Esto se debe a que, si fuera inherente al sustrato, la forma de sí mismo se obtendría para su sustrato y no para sí mismo, porque lo que es inherente por naturaleza solo puede existir en su sustrato. Y esto implica una contradicción." $(2015,253$.

Sobre este pasaje sadriano Faruque realiza la siguiente observación:

"Esto se debe a que, si la percepción de algo consistiera en captar su forma en el perceptor, quien se percibe a sí mismo sería diferente del lugar de percepción, que es ella misma. Esto resulta en una contradicción porque sería como decir "me percibo" y sin embargo "no me percibo", ya que "yo" y mi "yo" son diferentes, lo cual es inadmisible. $(2021,115)^{15}$

Vale mencionar, a la par de la investigación de Faruque, el trabajo de Jari Kaukua con "A Closed Book: The Opacity of the Human Self in Mulla Sadra” (2014), que continua esta línea investigativa sobre la autoconciencia, y sobre todo la obra de Sümeyye Parıldar con su texto "Intentionality in Mullâ Sadrâ" (2020), donde realiza un estudio analítico de las ideas de Șadrâ en cuanto al alma, la existencia y la percepción, construidas alrededor del problema de la intencionalidad en la óptica de bretaniana y las ideas de Meinong, Russell y

\footnotetext{
${ }^{15}$ Después de hablar sobre la conciencia de primer y segundo orden, Șadrâ también aborda el tema de cómo uno puede ser consciente de los demás. Aborda la experiencia fenomenológica de la vergüenza (al-khajâla) para arrojar luz sobre la conciencia que uno tiene de los demás: "Si a un ser humano se le ocurre la conciencia de que otros
}

Quine. A juicio de esta investigadora de la Facultad de Filosofía de la Universidad de Estambul:

\begin{abstract}
"La ontología y psicología de Mullâ Șadrâ no solo brindan un enfoque más amplio de la intencionalidad, sino que también ofrecen respuestas únicas sobre qué es la intencionalidad y cuál es la naturaleza de un objeto intencional. Su comprensión de la existencia involucra fenómenos mentales que emergen como una respuesta ontológica diferente a la de Russell y Meinong, además de ser diferentes de Avicena y Suhrawardî. Además, la idea de Șadrâ de la naturaleza creativa del alma humana trae una explicación innovadora de cómo funciona la intencionalidad. Esto es exclusivo de él. Su relato se basa en una comprensión dinámica y no esencialista de lo humano. Por lo tanto, algunos de los principios más singulares de su filosofía están relacionados con la cuestión de la intencionalidad y estas conexiones pueden proporcionarnos nuevos puntos de vista sobre la intencionalidad. Las contribuciones más originales de Mullâ Șadrâ (movimiento sustancial, ontología modulada (tashkīk) y su definición única del alma) están estrechamente relacionadas con mi pregunta. Aún más importante, su postura diferente ofrece la oportunidad de escapar de la dicotomía de material / inmaterial y presenta una alternativa a las filosofías esencialistas. La fuente de mi interés en el tema también está relacionada con estos puntos" $(2020,3)$.
\end{abstract}

Sümeyye Parıldar plantea el autoconocimiento y la conciencia como temas importantes para la epistemología sadriana. La explicación de Ṣadrâ sobre el proceso de producción de objetos de conocimiento es tan importante y explicativa como la noción de autoconocimiento, pues a través de la exploración de este proceso de producción se establece una visión importante de su comprensión del yo y del autoconocimiento. En este sentido, Parıldar afirma que el proceso de percepción es primordial en las discusiones sobre el autoconocimiento.

Podemos apreciar como el legado pitagórico- îshrâqî en Mullâ Șadrâ proporciona un análisis de la estructura ontofenomenológica de la conciencia que arrojará luz sobre la relación entre el yo, el autoconocimiento y la conciencia que desarrolló el pensamiento îshrâqî.

(shu 'âr bi-anna ghayrahu) han llegado a saber de un acto feo que ha cometido, entonces esa conciencia es seguida por un estado pasivo [mental] en su yo llamado vergüenza (al-khajāla).” [ Mullâ Șadrâ, Asfâr, 9: 107] 


\section{CONCLUSIÓN}

La germinación de la semilla pitagórica en la filosofía islámica posee actualidad en el desempeño de filósofos del presente como pueden ser los iraníes Sayyid Yadâllah Yaẓdânpanâh, Ali Amînî Nejâd y sobre todo el filósofo, îrfânî y matemático Hasan Zâdeh Âmulî (1929-2021). Sería pertinente bajo esta línea de pesquisa abordar en el futuro las implicaciones pitagóricas de Empédocles en el contexto filosófico islámico, donde los conceptos empedoclianos de isonomía, rizomatas y principios combinatorios (alternancia entre lo uno y lo

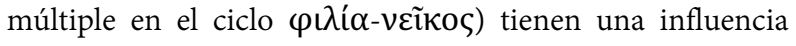
inmediata en la corriente de pensamiento îshrâqî y en el pensamiento místico o îrfânî. Esto deja abierto el espacio para continuar la búsqueda de la rica herencia pitagórica en el contexto de las ideas filosóficas islámicas, ideas en las que cabría asumirse la frase de Hermann Hesse en "El juego de los abalorios" al decir: "Pues, como todas las grandes ideas, no tiene de hecho un comienzo, sino que existió desde siempre en calidad de tal idea... Lo hallamos prefigurado ya en muchas épocas anteriores como concepto, como intuición, como forma mágica, por ejemplo, en Pitágoras..." 


\section{REFERENCIAS}

Abbâs-zâdeh, M. (2016). Naḍ̂m-e ma'arafat shenâsî Îshrâqîe Suhrawardî. Qom: S. Andîŝe Islamî.

Aldama, A. (2021). Significados y evolución del término inniyyat en la filosofía islámica clásica y contemporánea. Revista de investigación filosófica y teoría social Dialektika, 3(7), 1-23.

Arab, H. (2002). Farhang nâmeh Suhrawardî. Teherán: Hurmus.

Avicena. (2016). Kitab al-Isharât va al-tanbihat. Qom: Bustan-e Ketab.

Colli, G. (2008). La sabiduría griega I. Madrid: Trotta.

Colli, G. (1977). El nacimiento de la filosofía. Barcelona: Tusquets.

Colli, G. (2020). Apolíneo y dionisíaco. Ciudad MéxicoMadrid: Sexto Piso.

Corbin, H. (2002). El encuentro con el ángel. Tres relatos visionarios. Madrid: Trotta.

Corbin, H. (2006). Cuerpo espiritual y Tierra celeste: Del Irán mazdeísta al Irán chiíta. Madrid: Siruela.

Corbin, H. (2014). Les motifs zoroastriens dans la Philosophie de Sohrawardi. Teherán: Iranian Institute of Philosophy.

Da Silva, M. (2019). La métaphysique des lumières de Suhrawardī et la question de la connaissance divine. MIDÉO, 64, 147-197.

Dashtakî, M. (2003). Îshrâq hayâkil al-nûr. Teherán: Mirashi maktub.

Dînânî, I. (2006). Sho' â'a ândîsheh wa shuhûd dar falsafeh Suhrawardî. Teherán: Hikmat.

Dînânî, I. (1998). Khūd-āgāhī mahs ū l-i suvar-i idrākī nīst. Teherán: Hikmat.

Falsafi, H. (2002). Manțeq Ishrâq. Qom: Bustan-e Ketab.
Faruque, M (2021). "Sculpting the Self: Islam, Selfhood, and Human Flourishing", Michigan: University of Michigan Press Ann Arbor.

Gihamy, G. (1998). Muștalahât al-falsafat 'inda al- 'arab. Beirut: Librairie du Liban Publishers.

Gorman, P. (1988). Pitágoras. Barcelona: Editorial Crítica.

Hernández de la Fuente, D. (2011). Vidas de Pitágoras. Girona: Ediciones Atalanta.

Jaeger, W. (1971). Paidea, los ideales de la cultura griega. Habana: Editorial Ciencias Sociales.

Kâshânî, K. (2005). Tahlîyat al-Arwâh Bihaqâ íq al-injâh. Teherán: Mirash-i maktub.

Kammûna, I. (2003). Al-Kâshif, al-Jadîd fîl-hikma. Teherán: Mu'saseh hikmat wa falsafeh-e irani.

Karayi, A. (1996). Estelâhât-e falsafi wa tafâwot-e ânhâ bâ yekdigar. Qom: Bustan-e Ketab.

Kaukua, J. (2015). Self-awareness in Islamic philosophy: Avicenna and beyond. Reino Unido: Cambridge University Press.

Kaukua, Jari (2020). I'tibārī Concepts in Suhrawardī: The Case of Substance. Leiden: Oriens. 48, 40-66.

Kaukua, Jari (2014). A Closed Book: Opacity of the Human Self in Mullâ Ṣadrâ. Vivarium, 52, 241-260.

Kirk, C. S. (2014). Los filósofos presocráticos: Historia crítica con selección de textos II. Madrid: Gredos.

Kobayashi, H. (1990) Ibn Sīnā and Suhrawardī on SelfConsciousness. Some Comparative Remarks. Orient: 26, 62-77.

Marcotte, R. (2006). l'aperception de soi chez Shihāb al-Dīn al-Suhrawardī et l'héritage avicennien. Laval théologique et philosophique, 62 (3), 529-551.

Parıldar, S. (2020). Intentionality in Mullâ Șadrâ. Suiza: Editorial Springer. 


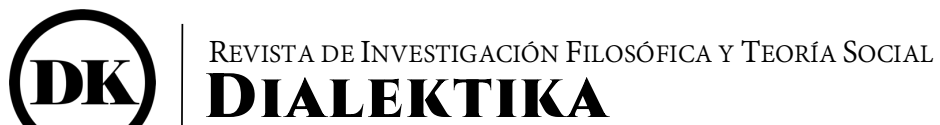

Qifṭ̂, I. (2018). Ta 'rîh al-ḥukamâ. Teherán: Dâneshgâh-e Teheran.

Renger, A.B. ed. (2016). Pythagorean Knowledge from the Ancient to the Modern World: Askesis, Religion, Science. Berlín: Harrassowitz Verlag · Wiesbaden.

Riedweg, Ch. (2005). Pythagoras: His Life, Teaching, and Influence. New York: Cornell University Press.

Șadrâ, M. (2004). Sharḥ Hikmat al-ishrâq. Teherán: Entezârât Hikmat Islami Șadrâ.

Șadrâ, M. (2015). Al-Shawâhid al-rubûbiyya fi l-manâhij alsulûkiyya. "(edición árabe, con introducción y notas de Yalâl al-Dîn Âshtiyânî, y el comentario de Hâdî Sabzavârî). Qom: Bustân-e Ketâb.

Șadrâ, M. (2018). Al-Hikma al-muta 'âliya fî l-asfâr al'aqliyya al-arba'a (edición árabe de Reza al-Zhanî con notas al pie de Al-Nûrî Ișfahânî, Hâdî Sabzavârî, Modarres Zonûzî, Alî Nûrî, Ali H. AlZanyânî y A. Husein Tabâțabâ'î), 9 Tomos. Qom: Enteshârât țalî'ah nûr.

Șadrâ, M. (2018). "Mafâtiḥ al-gayb” ("Las llaves del Mundo Invisible"). Teharán: Ishârât Maûla.

Segovia, C. (2005). Șadr Ad-Dîn Šîrâzî, la filosofía islámica y el problema del ser. Estudio y comentario del Kitâb al mâs $\bar{a}^{\prime}$ ir. Granada: Universidad de Granada.

Shahrazûrî, M. (1993). Sharh Hikmat al-ishrâq. Teherán: Mu'saseh mutaal'eat wa tahaqiqat farhangi.

Shahrazûrî, M. (2005). Rasâ'il al-shajarah al-ilâhiyyah. Teherán: Mu’saseh hikmat wa falsafeh-e irani.

Shîrâzî, Q. (2005). Sharh Hikmat al-ishrâq. Teherán: Hikmat.

Suhrawardî, Y. (2014). Hikmat al-ishrâq. Qom: Dâneshgâh ulume Dîni.

Suhrawardî, Y. (2015). Lamahât fi-al-haghâegh. Qom: Dâneshgâh ulume Dîni.

Suhrawardî, Y. (2015). Talwihât al-Luwhiyyati va alarshiyyat. Qom: Dâneshgâh ulume Dîni.
Yazdânpanâh, S. (2016). Omûzesh Hikmat Îshrâq. Qom: 'Ulûm-e Insânî.

Zambrano, M. (2012). El hombre y lo divino. México: Fondo Cultura Económica.

Zhang, T. (2019). Light in the Cave. A Philosophical Enquiry into the Nature of Suhrawardī's Illuminationist Philosophy. Londres: Cambridge University.

Ziai, H. (1995) Shihâb al-Dîn Suhrawardî: founder of the Iluminationist school. En, History of Islamic Philosophy. Londres: Routledge, 1995. Cap. 28, 434464. 